\title{
STX11 Gene
}

National Cancer Institute

\section{Source}

National Cancer Institute. STX11 Gene. NCI Thesaurus. Code C114618.

This gene plays a role in the targeting and fusion of intracellular transport vesicles. 